Medical Center, St Francis Hospital, Straub Clinic and Hospital, Tripler Medical Center, Wahiawa General Hospital, and the Hawaii Tumor Registry. We thank Dr Marc Micozzi for helpful discussions. The study was supported by grant ROI CA 33644 awarded by the National Cancer Institute, Department of Health and Human Services, Bethesda, Maryland.

1 Talamini R, La Vecchia C, Decarli A, Negri E, Franceschi S. Nutrition, social factors and prostatic cancer in a northern Italian population. Br $\mathrm{f}$ Cancer 1986;53:817-21.

2 Snowdon DA, Phillips RL, Choi W. Diet, obesity and risk of fatal prostate cancer. Am Y Epidemiol 1984;120:244-50.

3 Garfinkel L. Overweight and morality. Cance 1986:58:1826-9.

4 Worth R, Kagan A. Ascertainment of men of Japanese ancestry in Hawaii through world war II selective service registration. $\mathcal{F}$ Chronic Dis 1970;23: 389-97.

5 Heymsfield SB, McManus C, Smith J, Stevens V, Nixon DW. Anthropomorphic measurements of muscle mass: revised equations for calculating bone-free arm muscle area. Am f Clin Nutr 1982;36:680-90.

6 Frisancho AR. New norms of upper limb fat and muscle areas for assessment of nutritional status. Am f Clin Nutr 1981;34:2540-5.
7 Cox DR. Regression models and life tables (with discussion). Journal of the Royal Statistical Society, Series B 1972;34:187-220.

8 Garn SM, Leonard WR, Hawthorne VM. Three limitations of the body mas index. Am $\mathcal{F}$ Clin Nutr 1986;44:996-7.

9 O'Malley BW. Mechanism of action of steroid hormones. $N$ Engl $\mathcal{J}$ Med 1971;284:370-7.

10 Pour PM, Stepan K. Induction of prostatic carcinoma and lower urinary tract neoplasms by combined treatment of intact and castrated rats with testosterone propionate and $\mathrm{N}$-nitrosobis (2-oxopropyl) amine. Cancer Res 1987;47:5699-706

11 Chisholm GD, Habib FK. Endocrine aspects of aetiology of carcinoma of the prostate. In: Adlercreutz H, Bulbrook RD, Van der Molen HJ, Vermeulen prostate. In: Adlercreutz H, Bulbrook RD, Van der Molen $\mathrm{H}$, Vermeulen Amsterdam: Excerpta Medica, 1981. (Research on steroids volume 9.)

12 Cowart V. Steroids in sports: after four decades, time to return these genies to bottle? JAMA 1987;257:421-7.

13 Hall R, Anderson J, Smart GA, Besser GM. Clinical endocrinology. Philadelphia: Lippincott, 1974:208-10.

14 Braunwald E, Isselbacher KJ, Petersdorf RG, Wilson JD, Martin JB, Fauch AS, eds. Harrison's principles of internal medicine. New York: McGraw-Hill, 1987:1759-69.

15 Walter JB. An introduction to the principles of disease. Philadelphia: Saunders, 1982:555-7.

(Accepted 10 May 1988)
Departments of Medicine and Obstetrics and Gynaecology, Brigham and Women's Hospital, Harvard Medical School, Boston, Massachusetts 02115, United States Janet Lang, PHD, associate epidemiologist

Ellice Lieberman, MD instructor, obstetrics and gynaecology

Department of Obstetrics and Gynaecology, St George's Hospital Medical

School, London SW17 0RE J Malcolm Pearce,

MRCOG, senior lecturer

\section{Department of Obstetrics} and Gynaecology, King's College Hospital, London SE5

Linda Cardozo, MRCOG, consultant

\title{
Prolonged pregnancy: the management debate
}

In 1986 we published a paper on the management of prolonged pregnancy by Ms Cardozo and her colleagues (25 October 1986, p 1059). Drs Lang and Lieberman wrote to us suggesting an additional analysis of the data, to which $\mathrm{Mr}$ Pearce and Ms Cardozo responded. We here publish the details and results of this supplementary analysis.

\section{Suggested supplemental analysis}

\section{Janet Lang, Ellice Lieberman}

The study by Cardozo et al was the largest randomised clinical trial to date designed to evaluate strategies for managing prolonged pregnancy. In the study 402 women were randomised either to have their labour induced two to four days later (active group; $n=195$ ) or to have their pregnancy observed without any intervention, unless intervention was medically indicated (conservative group; $n=207$ ). For the active group the time between assignment to the group and induction of labour was no doubt necessary to allow the women time to make necessary practical arrangements. During this time, of course, spontaneous labour could occur; for 49 women (25\%) in the active group it did, and another 21 women $(11 \%)$ refused to undergo the treatment assigned to them and were therefore not induced at the scheduled time. Thus only 125 of the 195 women $(64 \%)$ assigned to the active group actually had their labour induced.

The analysis performed by Cardoza et al was classical -that is, by intention-to-treat. Because of the relatively high levels of non-compliance with assigned treatment, however, we suggest a supplemental analysis. The first step would be an attempt to adjust for differences between the group assignment and the treatment received that resulted from the necessary two to four day waiting period between randomisation and planned induction. The critical feature of this approach (figure) is to apply the constraint of completing the two to four days' waiting time to both groups before assessing outcomes relevant to the study. During this waiting time spontaneous labour may begin, labour may be induced for medical reasons, or women may refuse the treatment assigned to them. The expectation, of course, is that the prevalence of spontaneous labour and medically required inductions would be quite comparable across the two groups. All the women in the active group who completed the waiting period will thus have had their labour induced. Of those randomised to the conservative group, the subgroup for analysis will, quite appropriately, contain women who began labour spontaneously after the waiting time; women who were induced after the waiting time because of complications; and women who requested induction after the waiting time. The second step would be to compare these two subgroups. This comparison would not be a randomised comparison. Thus, analytical techniques for observational studies (such as multivariate analyses) must be used so that appropriate attention is given to the control of confounding in the crude comparison of the two groups. Otherwise, the effects of bias might well contribute to the observed effects.

\section{Results}

\section{J Malcolm Pearce, Linda Cardozo}

We thank Drs Lang and Lieberman for suggesting the interesting supplementary analysis to our paper on the management of prolonged pregnancy. The waiting time was introduced into our trial not only to allow women to make appropriate arrangements but also to overcome the problem of intervening weekends. After performing the suggested analysis we found that 70 women $(36 \%)$ in the active group went into spontaneous labour during the waiting time compared with 41 women $(20 \%)$ in the conservative group. This difference was significant $\left(\chi^{2}=12 \cdot 2, p<0.001\right)$ and our only explanation for this difference is that it may have been a result of the vaginal examination performed to assess the cervix before planned induction. This examination may not have been performed on the women in the conservative group, but unfortunately we cannot verify this. An additional 10 women from the conservative group required indu'ction during the waiting time (three for hypertension, two because of worrying results from cardiotocography, two for premature rupture of the membranes, and three because they requested induction of labour).

This left 125 women in the active group, who all had their labour induced after completing the waiting time, and 156 women in the conservative group. As in our original analysis, the conservative group contained significantly more white women $(p<0.02)$, but the groups were otherwise well matched (table I). At the onset of labour, however, significantly more fetal heads 
Supplementary analytical scheme to evaluate outcome of active and conservative management of women with prolonged pregnancies

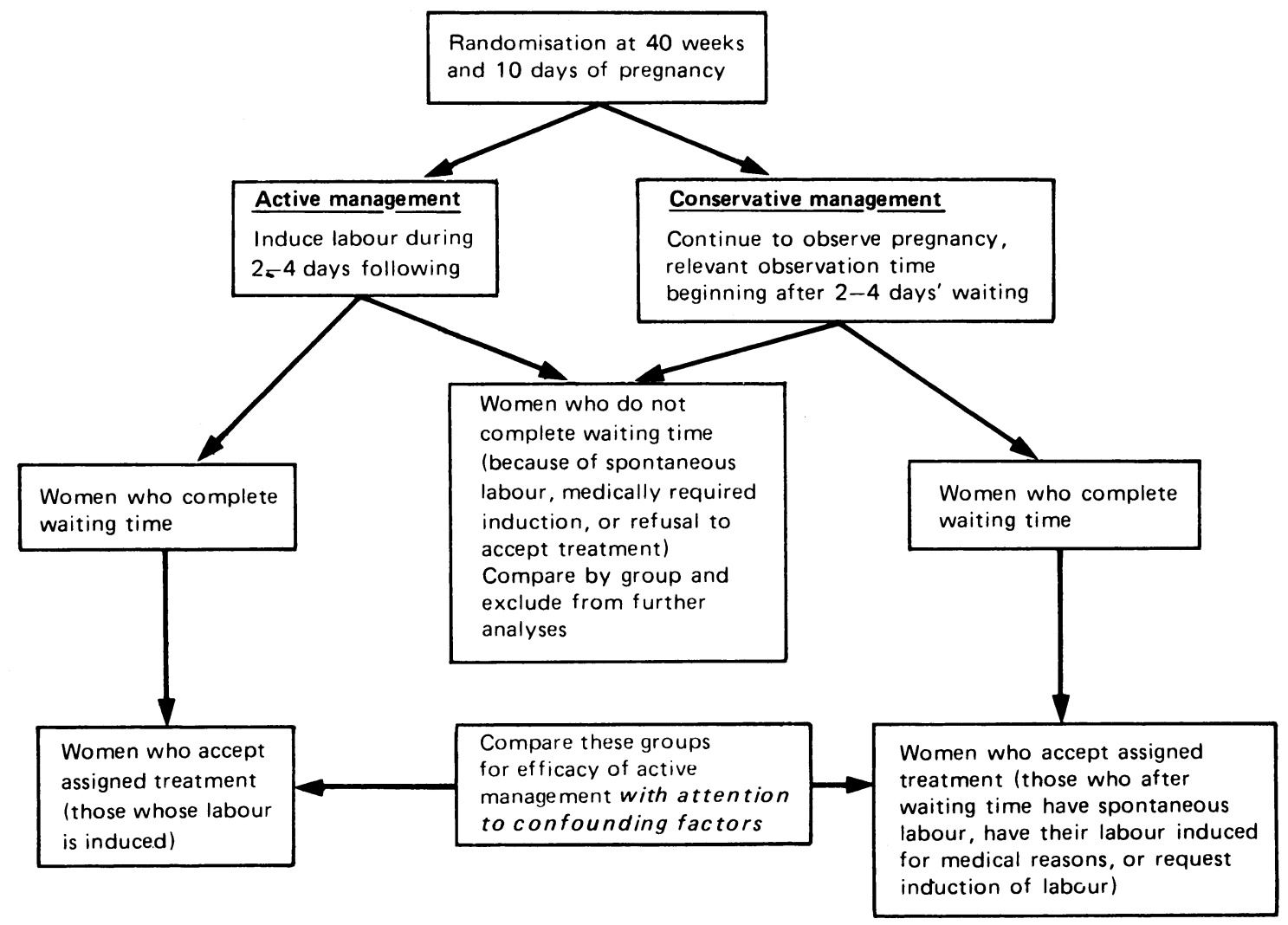

were engaged and the mean Bishop's score was higher in the conservative group.

Significantly more fetuses of patients in the active group showed heart rate abnormalities during the first stage of labour $(14 \% v 7 \% ; \mathrm{p}<0.02)$, and in cases in which fetal scalp $\mathrm{pH}$ was measured values of less than $7 \cdot 25$ were found only in fetuses of patients in the active group. Furthermore, the trend towards an increased incidence of caesarean section for fetal distress shown in our original analysis became significant $(6 \% v 1 \%$; $\left.\chi^{2}=4 \cdot 18, \mathrm{p}<0.05\right)$.

No differences were observed between the two groups in the second stage of labour or in the short term neonatal outcome (tables II and III). The umbilical venous $\mathrm{pH}$ was, however, significantly less acidotic in babies born to mothers in the conservative group.

TABLE I - Details of patients who completed 42 weeks' gestation. Unless stated otherwise results are numbers (percentages) of patients

\begin{tabular}{|c|c|c|c|}
\hline & $\begin{array}{l}\text { Active } \\
\text { group }\end{array}$ & $\begin{array}{l}\text { Conservative } \\
\text { group }\end{array}$ & $\begin{array}{l}\text { Significance } \\
\text { ( } \mathrm{p} \text { value) }\end{array}$ \\
\hline No of patients & 125 & 156 & \\
\hline Mean (SD) age (years) & $26 \cdot 2(5 \cdot 2)$ & $25 \cdot 6(4 \cdot 9)$ & NS \\
\hline Primiparas & $58(46)$ & $88(56)$ & NS \\
\hline \multicolumn{4}{|l|}{ Race: } \\
\hline White & $91(73)$ & $129(83)$ & $\mathrm{p}<0.02$ \\
\hline Black & $24(19)$ & $19(12)$ & \\
\hline Asian & $10(8)$ & $4(3)$ & \\
\hline Other & 0 & $4(3)$ & \\
\hline Smokers & $36(29)$ & $45(29)$ & \\
\hline Mean (SD) gestation (days) & $294 \cdot 0(2 \cdot 6)$ & $297 \cdot 8(3 \cdot 9)$ & $\mathrm{p}<0.001$ \\
\hline Mean (SD) Bishop's score & $5 \cdot 5(3 \cdot 1)$ & $8.0(3 \cdot 8)$ & $\mathrm{p}<0.001$ \\
\hline \multirow{2}{*}{\multicolumn{4}{|c|}{$\begin{array}{l}\text { Level of fetal head (less than } \\
\text { two fifths palpable) }\end{array}$}} \\
\hline & $43(34)$ & $99(64)$ & $\mathrm{p}<0.001$ \\
\hline $\begin{array}{l}\text { Epidural analgesia } \\
\text { (SD) }\end{array}$ & $59(47)$ & $64(41)$ & NS \\
\hline $\begin{array}{l}\text { Mean (SD) length of first stage } \\
\text { (hours) }\end{array}$ & $8 \cdot 6(5 \cdot 2)$ & $7 \cdot 8(5 \cdot 0)$ & NS \\
\hline \multicolumn{4}{|l|}{ Intervention: } \\
\hline None & $108(86)$ & $141(90)$ & NS \\
\hline LSCS because of: & & & \\
\hline No progress & $7(6)$ & $7(5)$ & \\
\hline Failed induction & $3(2)$ & $4(3)$ & \\
\hline Elective & $0(0)$ & $2(1)$ & \\
\hline Fetal distress & $7(6)$ & $2(1)$ & $\mathrm{p}<0.05$ \\
\hline \multicolumn{4}{|l|}{ Cervimetric pattern: } \\
\hline Normal & $87(70)$ & $119(76)$ & NS \\
\hline Abnormal & $39(30)$ & $37(24)$ & NS \\
\hline Major CTG abnormality & $22(14)$ & $11(7)$ & $\mathrm{p}<0.02$ \\
\hline $\mathrm{pH}<7 \cdot 25$ & $8(6)$ & 0 & $\mathrm{p}<0.02$ \\
\hline
\end{tabular}

$\mathrm{NS}=$ not significant

LSCS = lower segment caesarean section CTG $=$ cardiotocography.
TABLE II - Details of patients during the second stage of labour. Unless stated otherwise results are numbers (percentages) of patients

\begin{tabular}{lccc}
\hline & $\begin{array}{c}\text { Active } \\
\text { group }\end{array}$ & $\begin{array}{c}\text { Conservative } \\
\text { group }\end{array}$ & $\begin{array}{c}\text { Significance } \\
\text { (p value) }\end{array}$ \\
\hline No of patients & 108 & 141 & \\
Mean duration (minutes) & $66 \cdot 2$ & $78 \cdot 8$ & NS \\
No intervention & $77(71)$ & $101(72)$ & NS \\
Intervention because of: & $15(14)$ & $26(18)$ & \\
$\quad$ Failure to progress & $11(10)$ & $9(6)$ & \\
$\quad$ Fetal distress & $5(5)$ & $5(4)$ & \\
$\quad$ Maternal exhaustion & $77(71)$ & $101(72)$ & NS \\
Mode of delivery: & $22(20)$ & $26(18)$ & \\
$\quad$ Spontaneous vaginal & $6(6)$ & $13(9)$ & \\
$\quad$ Traction forceps & $3(3)$ & $1(1)$ & \\
Rotation forceps & & \\
Emergency LSCS &
\end{tabular}

NS $=$ not significant. $\quad$ LSCS $=$ lower segment caesarean section.

TABLE III - Neonatal outcome. Unless stated otherwise results are numbers (percentages) of patients

\begin{tabular}{|c|c|c|c|}
\hline & $\begin{array}{l}\text { Active } \\
\text { group }\end{array}$ & $\begin{array}{l}\text { Conservative } \\
\text { group }\end{array}$ & $\begin{array}{c}\text { Significance } \\
\text { (p values) }\end{array}$ \\
\hline No of patients & 125 & 156 & \\
\hline \multicolumn{4}{|l|}{ Apgar scores: } \\
\hline$\leqslant 5$ at 1 minute & $19(15)$ & $16(10)$ & NS \\
\hline$\leqslant 5$ at 5 minutes & $1(1)$ & $2(1)$ & NS \\
\hline \multicolumn{4}{|l|}{ Meconium: } \\
\hline In pharynx & $14(11)$ & $18(12)$ & NS \\
\hline In trachea & $7(6)$ & $4(3)$ & NS \\
\hline Aspiration syndrome & $4(3)$ & $5(1)$ & NS \\
\hline Intubated & $17(14)$ & $11(7)$ & NS \\
\hline Admitted to SCBU & $5(4)$ & 1 & NS \\
\hline Mean (SD) birthweight (g) & $3670(500)$ & $3630(400)$ & NS \\
\hline Mean (SD) cord $\mathrm{pH}^{\star}$ & $7 \cdot 28(0 \cdot 10)$ & $7.33(0.08)$ & 0.006 \\
\hline
\end{tabular}

When Drs Lang and Leiberman saw our data they observed that during the waiting period seven women (3.4\%) from the conservative group required induction of labour on medical grounds compared with none in the active group, which was a significant difference $(\mathrm{p}<0.01)$. They suggested that differences in monitoring women planned for induction may have contributed to the increased incidence of abnormalities in fetal heart rate, low scalp $\mathrm{pH}$, and increased rate of caesarean section observed in this group.

We are not certain that grouping the seven women from the conservative group together is justifiable as 
two of them required induction for premature rupture of the membranes, and if these women are removed the statistical differences also disappear. Many obstetricians would not consider premature rupture of the membranes as a medical indication for induction as it does not pose such a threat to pregnancy as maternal hypertension or an abnormal antenatal trace of fetal heart rate. We realise, however, that others wish to see statistical significance as well as clinical significance, so we have reanalysed our data to include these seven women in the conservative group. This does not change the significance value given above as only one of the seven women had a caesarean section for fetal distress, detected as an abnormal cardiotocograph and a low scalp $\mathrm{pH}$ in the first stage of labour. The remaining women had spontaneous vaginal deliveries.

The supplementary analysis shows more clearly that routine induction of labour at 42 completed weeks of gestation significantly increased both the need for caesarean section for fetal distress $(6 \%$ v $2 \% ; 95 \%$ confidence interval $0 \%$ to $9 \%$ ) and the overall need for operative delivery for fetal distress ( $14 \%$ v $7 \%$; $95 \%$ confidence interval $0 \%$ to $14 \%$ ) with no effect on short term measures of neonatal outcome.

(Accepted 21 fuly 1988)

\section{Plasmacytosis and renal failure after readministration of streptokinase for threatened myocardial reinfarction}

\author{
N S Chan, Harvey White, Andrew Maslowski, \\ James Cleland
}

Green Lane Hospital,

Auckland, New Zealand

N S Chan, MRCP, cardiology registrar

Harvey White, FRACP, senior fellow, National Heart

Foundation of New Zealand James Cleland, FRACP, haematologist

Middlemore Hospital, Auckland, New Zealand Andrew Maslowski, FRACP, cardiologist

Correspondence to: Dr White.

Recent clinical trials have shown that early thrombolytic treatment with streptokinase reduces mortality and preserves left ventricular function after acute myocardial infarction. ${ }^{1.3}$ After successful reperfusion, however, the artery affected by the infarct may reocclude. Although streptokinase may be given again in an attempt to reopen the artery, there is a small risk of potentially serious allergic reactions. We describe such a rare event.

\section{Case report}

A 65 year old man was admitted to the coronary care unit with a half hour history of chest pain. Electrocardiography showed ST segment elevation in leads II, III, and AVF. Reperfusion was attempted with an infusion of 1.5 million units of streptokinase over 30 minutes. A heparin infusion was started at the same time and continued for 48 hours. Creatine kinase values were measured every two hours and an early peak rise of $1318 \mathrm{IU}$ was detected after 12 hours. The clinical course was uncomplicated until the fourth day, when he developed further chest pain associated with recurrent ST segment elevation in the inferior leads. He was given another dose of streptokinase ( 1.5 million units) over 30 minutes. Hydrocortisone was not given beforehand. Immediately after the streptokinase infusion he had rigors and became feverish. He had no rash or bronchospasm, and his blood pressure remained stable. Cardiac enzyme activities did not rise and recurrent myocardial infarction was prevented. Over the next few days, however, he developed a pronounced plasmacytosis and renal failure.

Initial investigations, including a full blood count, serum creatinine and urea measurements, and urine microscopy, gave normal results. On day 8 the total leucocyte count was $11 \cdot 5 \times 10^{4} / 1$, lymphocytes were $1.46 \times 10^{\%} / 1$, and a few "variant" lymphocytes were seen in the blood film. On day 9 an appreciable plasmacytosis was noted in the blood film, with a total leucocyte count of $17 \cdot 1 \times 10^{\%} / \mathrm{l}$, plasma cell count of $1 \cdot 20 \times 10^{9} / 1(7 \%)$, and plasma blasts count of $2 \cdot 22 \times 10^{9} / 1$ $(13 \%)$. Haemoglobin concentration was $156 \mathrm{~g} / \mathrm{l}$, platelets were $258 \times 10^{9} / 1$, and erythrocyte sedimentation rate was $46 \mathrm{~mm}$ in the first hour. Serum IgG concentration was $22 \cdot 8 \mathrm{~g} / \mathrm{l}$ with normal serum $\operatorname{IgA}$ and IgM values. Serum protein electrophoresis showed a diffuse increase in gammaglobulins without a monoclonal band. Serum C 3 was $1.67 \mathrm{~g} / 1$ and serum C4 $0.43 \mathrm{~g} / \mathrm{l}$. The urine protein value was ++ ; the sediment contained many leucocytes and fine granular casts, few hyaline casts, and no erythrocytes or erythrocyte casts. Electrophoresis of a concentrated urine sample showed a large amount of protein but no free light chains. The antistreptolysin $\mathrm{O}$ titre was 340 IU. Antinuclear antibodies were absent, and a direct Coombs test gave a negative result. His renal function, previously normal, deteriorated on day 8 with a serum urea value of $14.9 \mathrm{mmol} / \mathrm{l}$ and a serum creatinine value of $220 \mu \mathrm{mol} / \mathrm{l}$ (see figure). There was a subsequent progressive

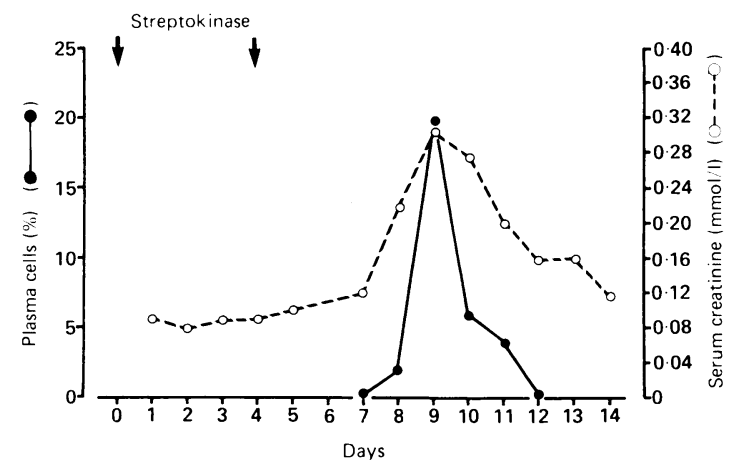

Relation between serum creatinine concentration, percentage of plasma cells, and time after administration of streptokinase

improvement in renal function, and the urea and creatinine concentrations had returned to normal by day 14. Plasma cells and plasma blasts had disappeared from the blood film by day 12 , when the total leucocyte count was normal.

The patient made a complete recovery and coronary artery surgery was performed for persisting severe angina.

\section{Comment}

Allergic reactions to streptokinase have been reported in $1 \cdot 7-18 \%$ of cases. ${ }^{4}$ The manufacturer's data sheet recommends that streptokinase should not be administered to patients who have received the drug five days to three months previously. We thought that it was safe for our patient to receive a second dose of streptokinase within four days of the initial treatment. To our knowledge there has been only one previous report of plasmacytosis after streptokinase treatment. ${ }^{5}$

The course of our patient's illness would suggest that the immune mechanism was an allergic or immune reaction to streptokinase with a dramatic rise in the number of plasma cells and plasma blasts after the second infusion of streptokinase. The high absolute plasmacytosis- $3.42 \times 10^{\%} / 1 \quad(20 \%)$, with a higher proportion of plasma blasts with a high nucleocytoplasmic ratio and nucleoli compared with plasma 